\title{
RELATIONSHIP BETWEEN BOTANICAL ORIGIN AND ANTIOXIDANTS VITAMINS OF BEE-COLLECTED POLLEN
}

Karla C. L. S. Oliveira, Marina Moriya, Ricardo A. B. Azedo e Ligia B. de Almeida-Muradian*

Faculdade de Ciências Farmacêuticas, Universidade de São Paulo. Av. Prof. Lineu Prestes, 580, 05508-900 São Paulo - SP, Brasil

Erica W. Teixeira e Maria L. T. M. F. Alves

Agência Paulista de Tecnologia dos Agronegócios, CP 07, 12400-970 Pindamonhangaba - SP, Brasil

Augusta C. de C. C. Moreti

Instituto de Zootecnia, Rua Heitor Penteado, 56, 13460-000 Nova Odessa - SP, Brasil

Recebido em 25/9/07; aceito em 8/1/09; publicado na web em 28/5/09

\begin{abstract}
This study quantified vitamin $\mathrm{C}, \mathrm{E}$ and $\beta$-carotene in samples of fresh bee-collected pollen and correlating them with the botanical origin. Vitamin content varied between 13.5 and $42.5 \mu \mathrm{g} / \mathrm{g}$ for vitamin E; 56.3 and $198.9 \mu \mathrm{g} / \mathrm{g}$ for $\beta$-carotene and $273.9 \mathrm{and} 560.3 \mu \mathrm{g} / \mathrm{g}$ for vitamin C. It was concluded that the botanical origin and collecting season influenced the vitamin contents. There is a relationship between the vitamins and its botanical origin: Raphanus sp and Macroptilium sp, Mimosa caesalpineafolia with $\beta$-carotene; Raphanus sp, Eucalyptus sp, Macroptilium sp, Mimosa caesalpineafolia with vitamin E and Anadenanthera sp, Arecaceae type and Philodendron sp with vitamin C.
\end{abstract}

Keywords: bee-collected pollen; vitamins; pollen analysis.

\section{INTRODUCTION}

Pollen can be collected and processed by beekeepers, without damage to the beehive and it is highly consumed around the world like a dietary supplement due its nutritive value. ${ }^{1}$ Nutrients are present in bee pollen like proteins, fatty acids, lipids, sterols, vitamins, minerals and certain carbohydrates. They can vary depending on time of collection, climatic conditions, plant age and botanical source..$^{2-4}$ Basically, it contains vitamins of B complex, vitamin C, D, E and carotenoids, ${ }^{5-7}$ but there are few data in literature about relationship between botanical origin and vitamin quantification. Muniategui et al. ${ }^{6}$ observed carotenes in pollen samples from Spain, AlmeidaMuradian et al. $^{8}$ observed the absence of vitamin $\mathrm{C}$ and $\beta$-carotene in a processed samples of bee pollen loads from the south of Brazil. These vitamins could be lost in the processing or their absence could be related with botanical origin because each pollen has its own specificity linked to the floral species or cultivars. ${ }^{9}$

The aim of this study is to quantify the three antioxidant vitamins (vitamin $\mathrm{C}, \mathrm{E}$ and $\beta$-carotene as provitamin $\mathrm{A}$ ) in fresh samples of bee pollen loads, correlating them with the botanical origin.

\section{EXPERIMENTAL}

\section{Materials}

Ten samples of fresh bee pollen loads were collected at Agência Paulista de Tecnologia dos Agronegócios (APTA), in Pindamonhangaba County ( $22^{\circ} 57^{\prime} \mathrm{S}, 45^{\circ} 27^{\prime} \mathrm{W}, 560 \mathrm{~m}$ ), São Paulo State, Brazil. Five samples were collected in April and five in October of 2005 .

The choice of the period for bee pollen samples collection for development of this experiment was based on the study performed by Silva et al. ${ }^{10}$ that observed during the period of 1968 to 1987 the nectarous flow of the region of Pindamonhangaba with the

*e-mail: ligiabi@usp.br purpose of establishing a bee calendar that would orient beekeepers in the optimization of bee-product production and consequently the best period for pollen collection (off-season of honey production).

Six beehives of the Langsthoth type of Africanized bees (Apis mellifera) were adapted with intermediate type collectors and maintained at conditions of pollen production.

Thirty support beehives were used for maintenance of the ideal conditions of suckling, so as to stimulate the pollen collection at meadow.

The beehives were weekly reviewed according to certain parameters, such as population, amount of situations with suckling, possibility of entrance of pollen, presence of the queen bee, and use of non-greased soy flour-based protein supplement as mentioned by Alves et al. ${ }^{11}$ and energetic (60\% sugar syrup).

\section{Sample preparation}

\section{For vitamins content}

Pollen samples were collected from each experimental beehive during the months of April and October, 2005, at three-day intervals. At the days of collection the amount of pollen from all the beehives was mixed and then composite samples were obtained. After 15 days, 5 composite samples were obtained, each containing in average 350 $\mathrm{g}$ of fresh bee pollen. Pollen samples were kept frozen at plastic bags until the vitamin and lipids quantification.

\section{For pollen analysis}

After obtaining the composite samples, an aliquot of $2 \mathrm{~g}$ was removed for pollinic analysis, later the slides were prepared in triplicate for each sample.

\section{For lipids content}

After vitamin quantification, the five composite samples, collected in April, were mixed and kept frozen at plastic bags until the lipid quantification. The same procedure was developed with pollen samples collected in October. 


\section{Standards and solvents}

HPLC grade solvents and analytical grade solvents were used. Alpha-tocopherol (Sigma T-3251) and ascorbic acid (Sigma A-5960) were used as external standard.

\section{Methods}

\section{Vitamin C content}

The method was based in $\mathrm{AOAC}^{12}$ and Oliveira ${ }^{13}$ and samples were weighted and transferred to centrifuge tube and then they were extracted twice with metaphosphoric acid - acetic acid aqueous solution at $14.000 \mathrm{rpm}$ for $10 \mathrm{~min}$. After this, the supernatant was transferred to volumetric flask of $50 \mathrm{~mL}$ and the volume was completed with the acid. This solution was potentiometric titrated with 2,6dichlorophenol-indophenol until end point of the titration. A standard solution was prepared (known concentration) with some reagents so it was titrated too. The results were applied in follow equation:

$\mu \mathrm{g}$ vitamin $\mathrm{C} / \mathrm{g}=\frac{\mathrm{Sc} \times \mathrm{V} \times 1000}{\mathrm{~W} \times \mathrm{V}}$

where Sc - standard concentration; V - volume used in sample titration; W - sample weight (dry-weight basis); V - volume used in standard solution titration.

The values are expressed on a dry-weight basis.

\section{Vitamin $E$ and $\beta$-carotene content}

For Vitamin E and $\beta$-carotene determination, samples were weighted and extracted with cool acetone (4 times) in a blender. The extract was filtered by vacuum and transferred to light petroleum in a separation funnel. This solution was washed by repeated additions of distilled water to remove traces of acetone. The vitamin extract was dried over anhydrous sodium sulphate and concentrated in a rotary evaporator $\left(\mathrm{T}=35^{\circ} \mathrm{C}\right)$.

\section{For vitamin E determination}

The residue was diluted with $5 \mathrm{~mL}$ of mobile phase (hexane: isopropyl alcohol 99:1), filtered $(0.45 \mu \mathrm{m})$, injected into the liquid chromatographer and quantified by HPLC-normal phase, with a silica column Shim-pack CLC-Sil (M) $25 \mathrm{~cm} .{ }^{14}$ The values are expressed on a dry-weight basis.

\section{For $\beta$-carotene determination}

The residue was diluted with portions of light petroleum and transferred to 2 x $30 \mathrm{~cm}$ glass open column chromatography (packed by pressing down with a cork stopper), using $\mathrm{MgO}$ :Hyflosupercel (1:2) and anhydrous $\mathrm{Na}_{2} \mathrm{SO}_{4}$ on the top. Light petroleum solution with increasing acetone concentrations (1,2 and 3\%) was used as mobile phase. The $\beta$-carotene band was cut out and eluted with acetone by vacuum and the solution was transferred to light petroleum (in a separation funnel), washed with distilled water and transferred to volumetric flask passing through anhydrous sodium sulphate. The extract was quantified spectrophotometrically and the absorption spectra were determined at $350-550 \mathrm{~nm}$ range..$^{15,16}$ The values are expressed on a dry-weight basis and calculated by follow equation:

$\mu \mathrm{g} \beta$-carotene $/ \mathrm{g}=\frac{\mathrm{abs} \times \mathrm{V} \times 10^{6}}{100 \times \mathrm{E}_{1 \mathrm{~cm}}^{1 \%} \times \mathrm{W}}$

where abs - sample absorbance; V - volume of volumetric flask; W - sample weight (dry-weight basis); E ${ }^{1 \%}$-2592 (absorptivity coefficient). ${ }^{17}$
Vitamin A quantification was done based on the pro-vitamin A activity of each carotenoid by the relation: $12 \mu \mathrm{g}$ of $\beta$-carotene is the same of a $1 \mu \mathrm{g}$ of retinol and 1 Retinol Activity Equivalent (RAE). ${ }^{18,19}$

\section{Pollen analysis}

To identify the pollen botanical source the collection, cataloguing, and taxonomic identification of floral species of a given region are important. This work consists in elaborating a regional herbarium or erxicate. Silva et al. ${ }^{20}$ during the period of 1975 to 1985 and Marchini et al.,${ }^{21}$ in the period of 1994 to 1997 inventoried the plants that were blooming and that were visited by Apis mellifera L. bees in Pindamonhangaba, thus developing the herbarium in the region (from which the pollen samples studied in this paper were collected).

After the preparation of erxicata, the pollinic analysis of the inventoried plants, a laminate of the collected pollen grains, and a card index with the pictures of the slides seen with microscopy were developed.

Pollen analyses were performed after acetolysis. ${ }^{22}$ So three pollen slides of each sample was prepared, microscopically observed and compared with the reference material for identification. The qualitative analyses were based on Moreti ${ }^{23}$ study and quantitative analyses were expressed as percentages after counting 300 pollen grains ${ }^{24,25}$ according the pollen classes defined by Louveaux. ${ }^{26}$ The frequency classes of pollen grains were attributed as dominant pollen (DP major of 45\%); accessory pollen (AP between 15 and 45\%); important isolated pollen (IIP between 3 and 14\%) and occasional isolated pollen (OIP minor of $3 \%$ ).

\section{Lipid content}

Lipid determination was made using Soxhlet extractor with diethyl ether as solvent (sample of $2 \mathrm{~g}$ ). ${ }^{27}$

\section{Statistical analysis}

To verify if there is variability between vitamin content in April and in October, an variance (ANOVA) analysis was made and appropriate T-tests applied.

\section{RESULTS AND DISCUSSION}

The differences found in this study for vitamin $\mathrm{E}, \mathrm{C}$ of $\beta$-carotene (pro-vitamin A) content, between the two important periods of bee pollen production in the region (off-season of honey production), occurred due to differences in the local flora between April and October, consequently there was a different contribution of botanical origin in the vitamin composition of samples.

Literature data inform $0.49-242.6 \mu \mathrm{g} / \mathrm{g}$ of total carotenoids in bee-collected pollen processed samples, $10 \mu \mathrm{g} / \mathrm{g}$ of $\beta$-carotene ${ }^{6} 152.0$ $640.0 \mu \mathrm{g} / \mathrm{g}$ of vitamin $\mathrm{C}^{5,7}$ and $0.10-0.32 \mu \mathrm{g} / \mathrm{g}$ of vitamin E. ${ }^{7}$ In this study the results varied from 273.9 to $560.3 \mu \mathrm{g} / \mathrm{g}$ for vitamin $\mathrm{C} ; 13.5$ to $42.5 \mu \mathrm{g} / \mathrm{g}$ for vitamin $\mathrm{E}$ and 56.3 to $198.9 \mu \mathrm{g} / \mathrm{g}$ for $\beta$-carotene. The difference is explained by the climatic differences, of floral contribution that are inherent and specific to the region and period of the year in which the samples are collected. The above-mentioned papers are from foreign authors, i.e., the values correspond to samples collected in other region under the influence of different condition of soil, weather, and botanical species. The vitamin content results are summarized on Table 1.

Table 2 presents pollen types observed in samples collected in October and April of 2005.

Observing vitamin content and pollen types it can suggest a relationship between these results. For vitamin C content, which has increased $60 \%$ in October, it can be related with the following pollen types: Arecaceae and Philodendron sp pollen and genus Anadenan- 
Table 1.Vitamin E, C and $\beta$-carotene determination in Brazilian fresh bee pollen collected in April and October of 2005

\begin{tabular}{|c|c|c|c|c|}
\hline \multicolumn{5}{|c|}{ Vitamin content $(\mu \gamma / \gamma)^{1,2}$} \\
\hline Season & Samples & $\mathrm{E}$ & $\mathrm{C}$ & $\beta$-carotene \\
\hline \multirow[t]{5}{*}{ April } & 1 & $32.3 \pm 2.3^{\beta}$ & $364.7 \pm 12.7^{\alpha}$ & $56.3 \pm 3.8^{\delta}$ \\
\hline & 2 & $42.5 \pm 2.7^{\alpha}$ & $273.9 \pm 8.6^{x}$ & $125.3 \pm 3.5^{\chi}$ \\
\hline & 3 & $33.3 \pm 1.9^{\beta}$ & $306.9 \pm 12.2^{\beta}$ & $151.5 \pm 13.2^{\beta}$ \\
\hline & 4 & $31.3 \pm 2.6^{\beta}$ & $327.1 \pm 15.8^{\beta}$ & $198.9 \pm 13.3^{\circ}$ \\
\hline & 5 & $31.1 \pm 1.4^{\beta}$ & $334.7 \pm 4.8^{\alpha \beta}$ & $195.6 \pm 1.8^{\alpha}$ \\
\hline \multirow[t]{5}{*}{ October } & 6 & $13.5 \pm 0.2^{\chi}$ & $537.3 \pm 0.9 x$ & ND \\
\hline & 7 & $14.9 \pm 0.4^{\beta}$ & $540.7 \pm 5.6^{x}$ & ND \\
\hline & 8 & $17.9 \pm 0.5^{\alpha}$ & $559.3 \pm 4.0^{\alpha \beta}$ & ND \\
\hline & 9 & $13.6 \pm 0.3^{x}$ & $560.3 \pm 2.9^{\alpha}$ & ND \\
\hline & 10 & $14.3 \pm 0.5^{\beta \chi}$ & $546.4 \pm 8.5^{\beta \chi}$ & ND \\
\hline
\end{tabular}

$\mathrm{n}=3$; (1) values expressed in average \pm standard deviation; (2) values with same letter in the same column $=$ no statistical difference $(\mathrm{p}$-value $<$ $0,05) ; \mathrm{ND}=$ not detected

Table 2.Porcentage of pollen types in pollen samples collected by Apis mellifera L. in Pindamonhangaba, State of São Paulo, Brazil in April and October of 2005

\begin{tabular}{|c|c|c|c|c|c|c|c|c|c|c|}
\hline \multirow{4}{*}{ Family Genus Specie } & \multicolumn{10}{|c|}{ Frequency $(\%)$} \\
\hline & \multicolumn{5}{|c|}{ April 2005} & \multicolumn{5}{|c|}{ October 2005} \\
\hline & \multicolumn{10}{|c|}{ Samples } \\
\hline & 1 & 2 & 3 & 4 & 5 & 1 & 2 & 3 & 4 & 5 \\
\hline Anadenathera sp. & & & & & & 2.6OIP & 13.7IIP & 8.6 IIP & 2.2OPI & 244 IIP \\
\hline Cecropia sp & & & & & & 1.1OIP & $1.4 \mathrm{OPI}$ & $0.2 \mathrm{OIP}$ & 4.6 IIP & $0.4 \mathrm{OIP}$ \\
\hline Eucalyptus sp & 55.9PD & 4.3AP & 19.1AP & 26.1AP & $15.33 \mathrm{AP}$ & 53.5PD & 34.6AP & 14.5IIP & $2.9 \mathrm{OIP}$ & 21.3AP \\
\hline Malvaceae & & & & & & $0.1 \mathrm{OIP}$ & & & & \\
\hline Mikania sp & & $0.7 \mathrm{OIP}$ & $0.1 \mathrm{OIP}$ & & $0.5 \mathrm{OIP}$ & & & & & \\
\hline Mimosa caesalpineafolia & $15.5 \mathrm{AP}$ & 48.2PD & 19.1AP & $1.2 \mathrm{OIP}$ & 21.9AP & $0.1 \mathrm{OIP}$ & & $0.1 \mathrm{OIP}$ & & \\
\hline Momordica charantia & $0.1 \mathrm{OIP}$ & & $1.7 \mathrm{OIP}$ & & & & & & & \\
\hline Philodendron sp & $0.10 \mathrm{IP}$ & & $0.10 \mathrm{IP}$ & & & $0.9 \mathrm{OIP}$ & 6.5IIP & 28.6AP & 17.7AP & 29.4APP \\
\hline Salvia spiedens & $0.6 \mathrm{OIP}$ & $0.5 \mathrm{OIP}$ & & $0.3 \mathrm{OIP}$ & 6.1 IIP & & & & & \\
\hline Solanum sp & 2.1OIP & & & & & & & & & \\
\hline Stenolbium sp & & $0.5 \mathrm{OIP}$ & & $1.7 \mathrm{OIP}$ & $2.2 \mathrm{OIP}$ & & & & & \\
\hline Tipo Arecaceae & $0.9 \mathrm{OIP}$ & & & & & 39.4AP & 29.8AP & 30.3AP & 4.7IIP & 15.1AP \\
\hline Tipo Myrcia & 4.1IIP & $1.5 \mathrm{OIP}$ & $0.1 \mathrm{OIP}$ & 3 OIP & $0.1 \mathrm{OIP}$ & $0.8 \mathrm{OIP}$ & $1.6 \mathrm{OIP}$ & $0.1 \mathrm{OIP}$ & 67.3PD & $0.4 \mathrm{OIP}$ \\
\hline Trema sp & & & $6.5 \mathrm{IIP}$ & & & & & & & \\
\hline Vernonia sp & $0.4 \mathrm{OIP}$ & & & & & & & & & \\
\hline Zinnia elegans & & & & & & $1.4 \mathrm{OIP}$ & 11.7IIP & 13.7IIP & & 4.3IIP \\
\hline
\end{tabular}

$\mathrm{n}=3$; * values expressed in average; $\mathrm{DP}=$ dominant pollen $(>45 \%$ of all grains $) ; \mathrm{AP}=$ accessory pollen $(15 \%-45 \%) ; \mathrm{IIP}=\mathrm{important}$ isolated pollen $(3 \%-14 \%)$; OIP $=$ occasional isolated pollen $(<3 \%)$.

thera and Eucalyptus. The Arecaceae type appears in October at all samples, in 4 of them as accessory pollen and in one of them as an important isolates pollen and it appears in April only in one sample as occasional isolates pollen. The percentage of genus Philodendron $s p$ in October is significant in 4 samples. In April, when vitamin C can also be seen in the samples, we may associate the contribution of genus Eucalyptus, Macroptilium sp and the Mimosa caesalpineafolia, species, all them appearing at significant amounts. However, the flora quality in October contributes to the increase of vitamin $\mathrm{C}$ content in this period of the year.
Vitamin E content, which has an increase of approximately 50\% in April, can be related with the following pollen types: Raphanus $s p$, Eucalyptus $s p$ and the specie Mimosa caesalpineafolia (appeared with the most frequency in April rather than in October) and genus Macroptilium (which appeared only in April). In October the vitamin E content can be associated to the genus Eucalyptus. The percentages of Mimosa caesalpineafolia, Raphanus sp, and Macroptillum sp are not significant in October, so this fact can contribute to decrease of vitamin E, but it may not be excluded that the other species predominant in this period and that do not occur 
at the same frequency in April contribute to the said vitamin, but at a smaller amount.

$\beta$-carotene only occurred in April, so probably none of the pollen types which appeared in October can be related with it. The genus Raphanus, the specie Mimosa caesalpineafolia and the genus Macroptilium sp, which basically appear only in April with a significant percentage could be related with $\beta$-carotene presence in pollen samples. The botanical types found in October did not contribute to the occurrence of $\beta$-carotene in this period, but other types of carotenoids that were not an object of this study were observed in samples.

In Table 3 can be observed the greater percentage of lipids in April, this fact may also be associated and it is justified the greater predominance of fat-soluble vitamins in this period - vitamin $\mathrm{E}$ and pro-vitamin A ( $\beta$-carotene).

Table 3. Lipids content in Brazilian fresh bee pollen collected in April and October of 2005

\begin{tabular}{lc}
\hline \multicolumn{2}{c}{ Lipids $^{1}$} \\
\hline Season & Lipids content $(\%)$ \\
April & $5.55 \pm 0.07$ \\
October & $2.65 \pm 0.04$ \\
\hline
\end{tabular}

$\mathrm{n}=3$; (1) values expressed in average \pm standard deviation

\section{CONCLUSIONS}

All of the samples contain antioxidants vitamins and some of them can be considered sources of specific vitamin. According to Directive \# 31 of January 13, 1998, ${ }^{28}$ at the labeling terms, a solid food is considered a source of specific vitamin or mineral if it provides $15 \%$ of the recommended diary intake ("IDR") in the product's specified proportion. The portion of recommended diary consumption for the dry bee pollen is up to $25 \mathrm{~g}$,

IDR for vitamin $\mathrm{C}$ is $90 \mathrm{mg} /$ day for man and $75 \mathrm{mg} / \mathrm{day}$ for woman, ${ }^{18}$ than the samples collected in October/2005 can be considered sources of vitamin $\mathrm{C}$ because they would provide between 13,4 and $14,01 \mathrm{mg}$ of this vitamin. For vitamin A, IDR is $900 \mu \mathrm{g} / \mathrm{day}$ for man and $700 \mu \mathrm{g} /$ day for woman. ${ }^{18}$ The pro-vitaminic value of the samples collected in April/2005 is between 4,7 and 16,6 $\mu \mathrm{g}$ (12 $\mu \mathrm{g}$ of $\beta$-carotene is the same of a $1 \mu \mathrm{g}$ of retinol), than these samples can be considered sources of vitamin A, because they would provide between 117,5 and $415 \mu \mathrm{g}$ of this vitamin. IDR for vitamin $\mathrm{E}$ is $15 \mathrm{mg} /$ day for adults $^{18}$ and $15 \%$ of this value consist in the ingestion of $2.25 \mathrm{mg}$ of vitamin $\mathrm{E}$, therefore the samples of bee pollen collected in April or in October could not be considered a source of such vitamin, because they only would provide between 0,34 and $1,06 \mathrm{mg}$ of this.

Due to the decreased number of analyzed samples, it cannot be accurately concluded on the specific floral contribution in the vitamins content but it is kwon that a species can contribute with more than one vitamin. A study with mono-floral analysis could be more accurate. In addition, the differences of blooming, meteorological factors and soil quality may interfere in the percentage of vitamins found in the bee pollen. Further studies on such relationship are necessary, manly in the same season and place to confirm these results.

\section{ACKNOWLEDGEMENTS}

Thanks are due to Conselho Nacional de Desenvolvimento Científico e Tecnológico (CNPq - Processo 472542/2004 - 4) and Fundação de Amparo à Pesquisa do Estado de São Paulo (FAPESP - Processo 2004/15100-1) for schoolarships and financial support

\section{REFERENCES}

1. Bastos, D. H. M.; Barth, O. M.; Rocha, C. I.; Cunha, I. B. S.; Carvalho, P. O.; Torres, E. A. S.; Michelan, M.; J. Apic. Res. 2004, 43, 35.

2. Herbet Jr., E. W.; Shimanuki, H.; Apidologie 1978, 9, 33.

3. Loper, G. M.; Standifer, L. N.; Thompson, M. J.; Gilliam, M.; Apidologie 1980, 11, 63 .

4. Krell, R.; Value-added products from beekeeping, FAO: Rome, 87, 1996 (FAO Agricultural Services Bulletin, v. 124).

5. Iannuzzi, J.; Am. Bee J. 1993, 133, 557.

6. Muniategui, S.; Sancho, M. T.; Lopez, J.; Huidobro, J. F.; Simal, J.; J. Apic. Res. 1990, 29, 147.

7. Hakim, H. ; Le pollen-aliment médicamente, Faculté de Meédicine de Bourdeaux, Paris, 1994, apud Lengler, S. ; Pólen apícola, Universidade Federal de Santa Maria, Santa Maria, 2002.

8. Almeida-Muradian, L. B.; Pamplona, L. C.; Coimbra, S.; Barth, O. M.; J. Food Compos. Anal. 2005, 18, 105.

9. Collin, S.; Vanhavre, T.; Bodart, E.; Bouseta, A.; J. Agric. Food Chem. 1995, 43, 444.

10. Silva, R. M. B.; Silva, E. C. A.; Moreti, A. C. C. C.; Alves, M. L. T. M. F.; Zootecnia 1995, 33, 137.

11. Alves, M. L. T. M. F.; Silva, E. C. A.; Moreti, A. C. C. C.; Silva, R. M. B.; Bol. Ind. Anim. 1997, 54, 85.

12 Association of Official Analytical Chemists; Official methods of analysis of AOAC International, $16^{\text {th }}$ ed., AOAC International: Arlington, 1995, Chapter 45, p. 16.

13. Oliveira, K. C. L. S.; Master dissertation, University of São Paulo, Brazil, 2006.

14. Presoto, A. E. F.; Rios, M. D. G.; Almeida-Muradian, L. B.; Boll. Chim. Ig. 2000, 7, 111.

15. Rodriguez, D. B.; Raymundo, L. C.; Lee, T. C.; Simpson, K. L.; Chichester, C. O.; Ann. Bot. 1976, 40, 615.

16. Almeida, L. B.; Penteado, M. V. C.; J. Food Compos. Anal. 1988, 1, 341.

17. Davies, B. H. In Chemistry and biochemistry of plant pigments; Goodwin, T. W., ed.; Academic Press: New York, 1976, vol. 2, p. 38165.

18. http://books.nap.edu/books/0309072794/html, acessada em Dezembro 2008.

19. Cozzolino, S. M. F.; Biodisponibilidade de nutrientes, Manole: São Paulo, 2005.

20. Silva, R. M. B.; Silva, E. C. A.; Moreti, A. C. C. C.; Alves, M. L. T. M. F.; Zootecnia 1993, 31, 59.

21. Marchini, L. C.; Moreti, A. C. C. C.; Teixeira, E. W.; Silva, E. C. A.; Rodrigues, R. R.; Souza, V. C.; Sci. Agric. 2001, 58, 413.

22. Erdtman, O. G. E.; Pollen morphology and plant taxonomy: angiosperms, Watham: Chronica Botânica; Almqvist \& Wiksell: Stockholm, 1952 (Introduction to Palynology, 1).

23. Moreti, A. C. C. C.; Marchini, L. C.; Souza, V. C.; Rodrigues, R. R.; Atlas do pólen de plantas apícolas, Papel Virtual: Rio de Janeiro, 2002.

24. Moreti, A. C. C. C.; Carvalho, C. A. L.; Marchini, L. C.; Oliveira, P. C. F.; Braganti 2000, 59, 1.

25 Carvalho, C. A. L.; Moreti, A. C. C. C.; Marchini, L. C.; Alves, R. M. O.; Oliveira, P. C. F.; Rev. Bras. Biol. 2001, 61, 63.

26. Louveaux, J.; Maurizio, A.; Vorwohl, G.; Bee World 1978, 59, 139.

27. Sakuma, A. M.; Kira, C. S.; Flora, C.; Cano, C. B.; Marsiglia, D. A. P.; Carvalho, M. F. H.; Mello, M. R. P. A.; Garbelotti, M. L.; Caruso, M. S. F.; Pascuet, N. S.; Zenebon, O.; Rodrigues, R. S. M.; Pimentel, S. A.; Métodos físico-químicos para análise de alimentos, Instituto Adolfo Lutz, 4a ed., ANVISA: Brasília, 2005.

28. http://e-legis.bvs.br/leisref/public/showAct.php?id=64\&word=, acessada em Dezembro 2008. 